\title{
Top Medical News Stories 2015
}

Here is our list of the top seven medical news stories for 2015 with special emphasis on the Southwest.

\section{Wearable health devices}

A wave of wearable computing devices such as Fitbit and UP wristbands have people keeping track of how much they sit, stand, walk, climb stairs and calories they consume (1). These fitness-tracking devices herald a series of devices that will detect and monitor serious diseases. However, these so-called medical-grade wearables require approval from the U.S. Food and Drug Administration, a regulatory hurdle avoided by the fitness-tracking devices which will likely slow their introduction.

\section{Caitlyn Jenner}

Caitlyn Jenner became the most famous transgender woman in the world following an interview published in Vanity Fair (2). The Vanity Fair website saw 11.6 million visits curious about the former Olympic athlete. Though Jenner publicly shared her gender identity, many transgender Americans do not-12\% of gender non-conforming adults said they had never told anyone about their gender identity. Jenner's "coming out" has and will likely continue to draw increasing attention to gender dysphoria. In Arizona, the Tucson VA recently established a transgender clinic (3).

\section{Ebola}

Two years after the beginning of an Ebola outbreak in West Africa, the virus continues to strike fear in the US. The Ebola outbreak sickened more than 28,630 people and killed at least 11,300, according to the World Health Organization (4). While the epidemic subsided in 2015, the virus has never completely gone away. The only Ebola cases today are in Liberia, a nation twice declared "Ebola free" suggesting that eliminating Ebola may be difficult.

\section{Terrorism in San Bernardino}

Multiple terror attacks have occurred in far off places like Afghanistan and Paris, but terror was brought to the Southwest in 2015 by 2 terrorists who killed 14 at a holiday party earlier in December in San Bernardino, California (5). The attack generated concern about emergency preparedness and will likely generate training for triaging and care of multiple gunshot victims.

\section{Vaccines}

A measles outbreak that started at Disneyland spread to 117 people earlier this year and changed the national conversation about vaccinations (1). The outbreak also drew attention to Disneyland's Orange County where a relatively large percentage of the population is not vaccinated. The outbreak spurred California and Vermont to strengthen their school vaccine laws. Vermont repealed its "personal belief" exemption, which allowed unvaccinated children to attend school if their parents objected to vaccines for philosophical reasons. California went even further, putting an end to both personal belief and religious exemptions. 


\section{Opioids}

Deaths from opioid drug overdoses have hit an all-time record in the U.S., rising 14 percent in just one year (6). More than 47,000 people died from these drug overdoses last year according to the CDC. Concomitant with the introduction of the pain scale as the "fifth" vital sign and continued criticism of doctors for undertreating pain, prescription opioid sales have quadrupled in the US since 1999. The CDC announced that it will issue guidelines to reduce opioid overdoses and prescribing.

\section{Prescription Drug Prices}

Concern over high drug costs has been building for years. Prices for cancer drugs often exceed $\$ 100,000$ a year and Gilead priced its breakthrough hepatitis C drug at $\$ 84,000$ for a 12-week treatment (4). Outrage over drug prices boiled over in 2015 when Turing Pharmaceuticals purchased the rights to pyrimethamine and immediately hiked the price from $\$ 13.50$ a pill to $\$ 750$ a pill. Pyrimethamine (Daraprim $®$ ) is a medication used for protozoal infections such as Toxoplasma gondii, an infection usually seen in AIDS patients. An October poll from the Kaiser Family Foundation found that $77 \%$ of those surveyed said that drug prices should be a top priority for Congress and the White House should and $63 \%$ favored government action to lower prescription drug prices.

Richard A. Robbins, MD

Editor, SWJPCC

\section{References}

1. Reddy S. Year in review: top 10 health issues of 2015. Wall Street Journal. December, 29, 2015. Available at: http://www.wsj.com/articles/year-in-review-top-10health-issues-of-2015-1451341107 (accessed 12/31/15).

2. Chalabi M. 2015: the top news stories of the year in numbers. The Guardian. December 28, 2015. Available at: http://www.theguardian.com/news/datablog/2015/dec/28/2015-news-stories-of-theyear-in-numbers-police-shootings-syria-gay-marriage-star-wars (accessed 12/31/15).

3. Transgender services. Available at: http://www.tucson.va.gov/services/Transgender Services.asp (accessed 12/31/15).

4. Szabo L. That $\$ 750$ pill and more: 2015 's top health stories. USA Today. December 15, 2015. Available at: http://www.usatoday.com/story/news/2015/12/15/fivemedical-stories-led-news-2015/77296624/ (accessed 12/31/15).

5. Domonoske C. San Bernardino shootings: what we know, one day after. NPR. December 3, 2015. Available at: http://www.npr.org/sections/thetwoway/2015/12/03/458277103/san-bernardino-shootings-what-we-know-one-day-after (accessed 12/31/15).

6. Siegel R. Draft of CDC's new prescribing guidelines stirs debate. NPR. December 29, 2015. Available at: http://www.npr.org/2015/12/29/461409296/draft-of-cdcs-newprescribing-quidelines-stirs-debate (accessed 12/31/15). 